\title{
Resilience and psychoanalysis: a systematic review
}

\author{
Bibiana Godoi Malgarim \\ Márcia Rosane Moreira Santana \\ Amanda Pacheco Machado \\ Universidade Federal do Rio Grande do Sul, RS, Brasil \\ Andre Goettems Bastos \\ Pontificia Universidade Católica do Rio Grande do Sul, RS, Brasil \\ Lúcia Helena Freitas \\ Universidade Federal do Rio Grande do Sul, RS, Brasil
}

\begin{abstract}
The aim of this paper was to investigate the concept of resilience by studying texts published in the field of psychoanalysis (over a ten-year period). Through a systematic review of articles published between 2004 and 2014, using descriptors in Portuguese, Spanish and English. Five data bases were searched, namely Pubmed, Lilacs, Scielo, BVS Index Psi and PsycInfo. We gathered 280 published items, including articles, papers, reviews and other types of material. After exclusion criteria, 11 articles were selected for analysis. The majority of the analysed articles were theoretical reviews. The concept of resilience in Psychoanalysis tends to be related to other concepts (e.g. trauma and violence). By itself it indicates an ability that was built fundamentally in through relationships: between subjects, and between subjects and their environments. The studies agree on the notion of resilience as a process that goes beyond simple adaptation. It is in fact an ability to survive, related to intra-psychic capabilities and early emotional experiences. In this respect, resilience emerges as a characteristic that is closely related to the social context of the subject. In fact, it develops from and within this context.
\end{abstract}

Keywords: Resilience; Psychoanalysis; Systematic review.

\section{Resiliência e psicanálise: uma revisão sistemática}

Resumo

O objetivo deste trabalho foi investigar o conceito de resiliência estudando textos publicados no campo da psicanálise (em um período de dez anos). Através de uma revisão sistemática de artigos publicados entre 2004 e 2014, usando descritores em português, espanhol e inglês. Foram pesquisadas cinco bases de dados: Pubmed, Lilacs, Scielo, BVS Index Psi e PsycInfo. Reunimos 280 artigos publicados, incluindo artigos, artigos, revisões e outros tipos de material. Após os critérios de exclusão, 11 artigos foram selecionados para análise. A maioria dos artigos analisados foram revisões teóricas. O conceito de resiliência na psicanálise tende a estar relacionado a outros conceitos (por exemplo, trauma e violência). Por si só indica uma habilidade que foi construída fundamentalmente através de relacionamentos: entre sujeitos e entre sujeitos e seus ambientes. Os estudos concordam com a noção de resiliência como um processo que vai além da simples adaptação. Na verdade, é a capacidade de sobreviver, relacionado às capacidades intra-psíquicas e às experiências emocionais iniciais. A este respeito, a resiliência surge como uma característica intimamente relacionada com o contexto social do sujeito. Na verdade, ela se desenvolve a partir de e dentro desse contexto.

Palavras-chave: Resiliência; Psicanálise; Revisão sistemática.

\section{Resiliencia y psicoanálisis: una revisión sistemática}

\section{Resumen}

El objetivo de este trabajo fue investigar el concepto de resiliencia mediante el estudio de textos publicados en el campo del psicoanálisis (durante un período de diez años). A través de una revisión sistemática de artículos publicados entre 2004 y 2014 , utilizando descriptores en portugués, español e inglés. Se realizaron búsquedas en cinco bases de datos, a saber, Pubmed, Lilacs, Scielo, BVS Index Psi y PsycInfo. Reunimos 280 artículos publicados, incluidos artículos, documentos, reseñas y otros tipos de material. Después de los criterios de exclusión, se seleccionaron 11 artículos para su análisis. La mayoría de los artículos analizados fueron revisiones teóricas. El concepto de resiliencia en el psicoanálisis tiende a estar relacionado con otros conceptos (por ejemplo, trauma y violencia). Por sí mismo, indica una habilidad que se construyó fundamentalmente en las relaciones: entre sujetos, y entre sujetos y sus entornos. Los estudios coinciden en la noción de resiliencia como un proceso que va más allá de la simple adaptación. De hecho, es una habilidad para sobrevivir, relacionada con capacidades intrapsíquicas y experiencias emocionales tempranas. En este sentido, la resiliencia emerge como una característica que está estrechamente relacionada con el contexto social del sujeto. De hecho, se desarrolla desde y dentro de este contexto.

Palabras clave: Resiliencia; Psicoanálisis; Revisión sistemática. 


\section{Introduction}

References to Resilience, as a term and as a concept, can be found in the literatures of both psychology and psychiatry, although its use is relatively recent (Rooke, 2015). According to Anaut (2005), the term resilience is widely used in the exact sciences. In physics, for example, resilience is defined as the amount of energy a material can absorb via deformation without losing its properties. That is, such material is able to return to its prior state after having been deformed. In psychoanalysis, the concept can be used to broaden a patient's clinical picture "as of the moment the subject is considered not only on the basis of their suffering and pathologies, but also in terms of their resources and skills." (Ostermann, 2011, p. 187).

Resilience may also be understood as the ability "to do well in the face of potential stressors" (Junqueira \& Deslandes, 2003). According to Cyrulnik (1999), the concept refers to a complex process involving extensive interaction between subject and environment. Cyrulnik (1999) points out that where there is resilience there is trauma, since trauma is the agent of resilience (Anaut, 2005).

Cyrulnik (1999) states that resilience is also modelled on an individual's ability to adapt to different environments and overcome problems. Given the complex interaction between the setting, the subject and other individuals in the environment, the subject in development perceives themselves within, or as the result of, these interactions, including the underlying adversities of the setting.

Ostermann (2011, p.172) points out that "resilience is born of and is nurtured by psychoanalysis, but it is not psychoanalysis itself." In other words, the important element here is that resilience is an inner attitude of the subject connected, at the same time, to the collective. Resilience does not relate solely to psychoanalysis nor is it alien to it, but not all the researchers who investigate the subject accept this perspective (Ostermann, 2011). According to Cabral and Levandowski (2013), for example, resilience was introduced into the field of psychoanalysis through either behavioural cognitive theory or positive psychology. Given the specificities of the theoretical constructs that underpin behavioural and positivist theories, it is important to stress that the two are similar in that they emphasize conscious aspects of the subject. In this respect, based on the premise that psychoanalysis has points of view that can stimulate debate over aspects beyond what is obvious, a very worthwhile space is opened up for investigating resilience.

Studies on resilience in the area of psychoanalysis are recent (Ungaretti, 2013), which means that this topic deserves a closer attention due to the limited amount of research and to its conceptual importance in today's society. In view of this scenario, we consider that a systematic review of the relationships between resilience and psychoanalysis constitutes an important task. Resilience is a relatively new concept in the field of psychology, and a specific investigation about the topic within psychoanalysis indicated that issues that are even more complex required careful attention. For these reasons, a systematic review was the method to configure the present research.

Systematic reviews can serve as important tools to strengthen studies with different designs, and they have been especially important in improving knowledge in the field of health care (Moher, Liberati, Tetzlaff $\&$ Altman, 2009). This method of investigation uses predetermined criteria established by the researchers in order to identify, organise and discuss published information and tends to generate consistent and critical assessments of new knowledge (Sampaio \& Mancini, 2007; Cruz, Zanon, \& Bosa, 2015). According to Costa and Zoltowski (2014), the use of this method in qualitative studies enables researchers to analyse articles based on their methods and results. It is therefore unnecessary to determine a single methodological design when choosing material to be studied.

The objective of this systematic review, therefore, was to analyse how psychoanalytic productions treat the concept of resilience as found in scientific articles selected from specific databases. This includes investigation into what themes the concept is associated with and which methods the articles in question apply. We also assessed other sources to understand how authors in the specialised literature deal with the concept of resilience.

An initial search through BVS and PubMed using the descriptor "Psychological Resilience" identified over 3,300 articles, a fact that clearly indicates the existence of ample production on this topic in the Psychology field - which does not apply to psychoanalysis. However, the present study has the more specific purpose of associating the concept of resilience with psychoanalytic production.

\section{Method}

This article describes a systematic review that discuss the concept of resilience in published psychoanalytic articles. We emphasize that the method used was based on the PRISMA model (Moher et al., 2009). However, the model can not be applied integrally due to the specificity of the subject of this study - most 
studies of psychoanalysis are qualitative and do not meet the requirements of PRISMA (Moher et al., 2009; Galvão, Pansani, \& Harrad, 2015). We searched the following databases: Pubmed, Lilacs, Scielo, BVS Index Psi and PsycInfo, and selected articles published between 2004 and 2014 in Portuguese, English and Spanish languages.

The descriptors used (based on a search through DeCs - Health Sciences Descriptors) were: Psychological Resilience AND Psychoanalysis; Psychological Resilience AND Psychodynamic Psychotherapy; Resiliência Psicológica AND Psicanálise (Portuguese); Resiliência Psicológica AND Psicoterapia Psicodinâmica (Portuguese); Resiliencia Psicológica AND Psicoanálisis (Spanish); and Resiliencia Psicológica AND Psicoterapia Psicodinámica (Spanish).

We used specific descriptors (shown above), which generated a total of 280 items, including articles, books, references to DVD documentaries and other material. In one of the first steps in the process we excluded duplicated items, as well as books and other material that seemed irrelevant to our objective. The result was a total of 56 texts, which were then submitted to two successive exclusion processes, reducing the number of articles, firstly to 29 and then to the final total of 11 .

After having identified the descriptors in the title of each article, we assessed the corresponding abstract. 280 articles and their respective abstracts were distributed to pairs of evaluators for final selection, applying the following inclusion criteria: the items had to have been published within the time period established, in English, Spanish or Portuguese, and had to include a definition of resilience. The criteria for exclusion were items addressing topics related to general organic diseases, as well as books, book reviews (epilogues or critiques) and visual material, such as DVDs. Research designs were not considered among the criteria, neither for inclusion nor for exclusion.

First we present results from the databases scanned using the descriptors mentioned above regarding the concept of resilience and how it is treated in psychoanalytic sources. Based on inclusion criteria for this study, we searched the databases using descriptors in the three languages specified above. Three items were identified in Scielo, 28 in PubMed, 19 in Lilacs and 230 in PsycInfo, and none in IndexPsi.

The searches were carried out over the first semester of 2015 and we divided all identified items between two pairs of evaluators, with one pair analysing 130 articles and the other, 150. We then selected or rejected the articles on the basis of the inclusion and exclusion criteria. This reduced the total to 56 items to be subjected to more detailed analysis. The flow chart below shows this process and includes the reasons for excluding some of the collected items. Whenever there was no agreement about any of the materials, a third pair of evaluators was called to take a decision based on thorough discussions carried out over meetings of the research team.

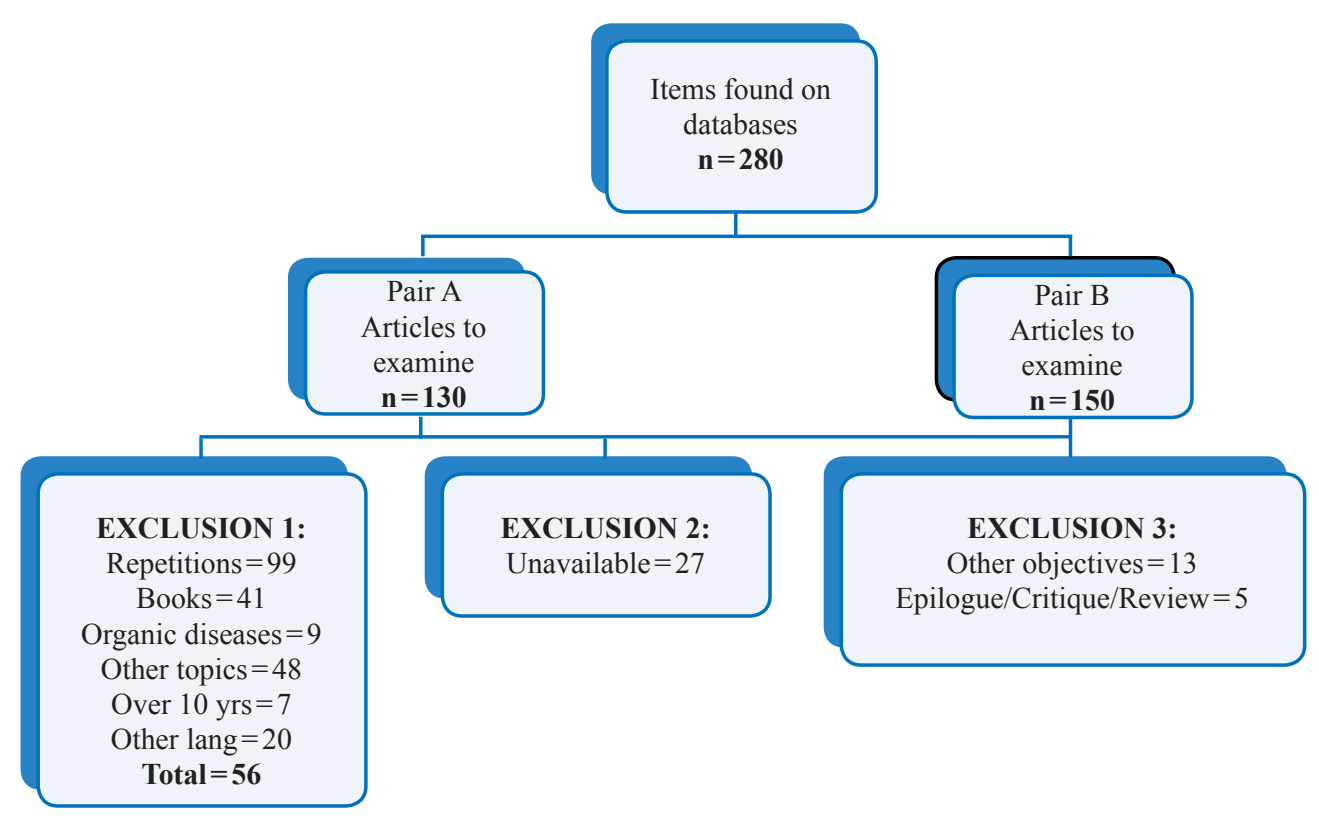

Figure 1. Flowchart depicting material collection and analysis procedures for this Systematic Review. Nota: Figura desenvolvida pelos autores do presente artigo. Todos os direitos autorais devem estar reservados. 
After bringing together the items that seemed to meet inclusion criteria, a second exclusion was necessary because 27 of the 56 items included were: a) no longer available, or, b) were no longer listed on any database. A detailed analysis led to a third exclusion process because 18 articles failed to fully meet the inclusion criteria either because they addressed topics different from those declared in the objectives of the present study $(n=13)$ or were not articles, but rather book reviews or epilogues $(n=5)$. As it can be seen in Figure 1, the final group of items to be analysed for this systematic review consisted of 11 scientific articles with varying methodological designs.

\section{Results}

The eleven articles ultimately analysed for the present study included five from Brazil, two from the United Kingdom and four from the United States. The earliest article (Benghozi, 2005) and the most recent (Cabral \& Levandowski, 2013) were both published in Brazil. The years of publication varied considerably, with no single year standing out in the number of articles published: one came out in 2005, three in 2006, one in 2007, two in 2011, three in 2012 and one in 2013.

Eight of the articles were theoretical reviews and the remaining were research reports. It should be noted that some theoretical studies do not specifically mention that they are of that type. This fact is shown in Table 1 under the category entitled "Theoretical Article (Undeclared)." Besides using the criterion of design, another category referred to the objectives of the items being analysed. This category included studies by Ostermann (2011), Cabral and Levandowski (2013), and Sordi, Manfro and Hauk (2011). In these cases the central aim was to focus on presenting and discussing the concept of resilience. The objectives of the remaining theoretical studies were related to resilience but based on psychoanalysis (Rosa, 2012; Benghozi, 2005), or consisted of narratives in the study of resilience (Hauser \& Golden, 2006). A number of articles had the objective of studying the relationships between pairs of concepts, such as ambivalence and resilience (Baraitser \& Noack 2007). Finally, two papers studied the personalities of subjects (Massie \& Szajnberg, 2006; Charles \& O'Loughlin, 2012). They are under the label "Research and Experience Reports."

In line with the objectives of this review, we identified the aforementioned articles in which the concept of resilience was associated with other topics.
We found some that are similar to one another but the differences among them were far greater than the similarities, with each article showing its own unique features. The concepts most commonly related to resilience were trauma and traumatism (Cabral \& Levandowkski, 2013; Charles \& O'Loughlin, 2012; Harris, 2006), followed by violence (Ostermann, 2011; Massie \& Szajnberg, 2006; Benghozi, 2005). In these latter cases, the question was related to specific outcomes, such as sexual abuse or incest. Resilience was also associated with other topics, such as intervention processes (Hauser \& Golden, 2006; Harris, 2006) (where psychotherapy and narratives are seen as experiences in re-signification). Other topics related to resilience included maternal resilience and ambivalence (Baraitser \& Noack, 2007), vulnerability (Rosa, 2012), defence mechanisms (Massie \& Szajnberg, 2013), personality disorders (Massie \& Szajnberg, 2013; Charles \& O'Loughlin, 2012), transitional space related to racism and creativity (LaMothe, 2012), and psychobiology (Sordi, Manfro, \& Hauk, 2011).

One of the items analysed was how articles present the concept of resilience. We found the word "adaptation" and the expression "adaptive ability" in articles by Cabral and Levandowski (2013) and Sordi, Manfro and Hauk, (2011). Two articles (LaMothe, 2012; Harris, 2006) failed to contain an exact definition of the concept that the authors were addressing.

The concept of vulnerability appears in an article by Massie and Szajnberg (2006), which discusses the effects of childhood sexual abuse on an adult personality. The authors emphasises one important aspect regarding resilience: care must be taken not to oversimplify the term, since adaptation itself does not mean resilience or mental health. In addition, in cases of violence, resilience emerges at the expense of vulnerability. In fact, the close association between resilience and vulnerability can be noted in the very history of the concept of resilience. For Brandão, Mahfoud and Nascimento (2011), this perspective was initially a result of the use of the term resilient as the equivalent of invulnerable, that is, it refers to subjects who, even in the face of risk situations, do not succumb. 
TABLE 1

Articles selected for final analysis, with journal name, year and design

\begin{tabular}{|c|c|c|c|c|}
\hline Title of Article & Authors & Year & Design & Theme \\
\hline $\begin{array}{l}\text { Resiliência e psicanálise: aspectos } \\
\text { teóricos e possibilidades de } \\
\text { investigação }\end{array}$ & $\begin{array}{l}\text { Cabral, S. A. } \\
\text { Levandowski, D. C. }\end{array}$ & 2013 & $\begin{array}{l}\text { Theoretical Article } \\
\text { (undeclared) }\end{array}$ & $\begin{array}{l}\text { It discusses the concept of resilience } \\
\text { and the main theoretical contexts of its } \\
\text { approach. }\end{array}$ \\
\hline $\begin{array}{l}\text { Potential space: creativity, resistance, } \\
\text { and resiliency in the face of racism }\end{array}$ & LaMothe, R. & 2012 & Theoretical Article & $\begin{array}{l}\text { It explores the notion of transitional } \\
\text { space, racism, creativity, and resilience. }\end{array}$ \\
\hline The complex subject of psychosis & $\begin{array}{l}\text { Charles, M. } \\
\text { O'Loughlin, M. }\end{array}$ & 2012 & $\begin{array}{l}\text { Original Article } \\
\text { (Report Research) }\end{array}$ & $\begin{array}{l}\text { It deals with the theme of trauma and } \\
\text { its psychosocial origin of psychosis in } \\
\text { Lacan's perspective. }\end{array}$ \\
\hline $\begin{array}{l}\text { Un aporte de la resiliencia a la clínica } \\
\text { psicoanalítica }\end{array}$ & Rosa, G. A. M. & 2012 & $\begin{array}{l}\text { Theoretical Article } \\
\text { (undeclared) }\end{array}$ & $\begin{array}{l}\text { It presents the psychoanalytic theories } \\
\text { and the concept of resilience to rethink } \\
\text { the current clinical context. }\end{array}$ \\
\hline Incesto e resiliência & Ostermann, G. & 2011 & $\begin{array}{l}\text { Theoretical Article } \\
\text { (undeclared) }\end{array}$ & Incest and resilience \\
\hline $\begin{array}{l}\text { O Conceito de Resiliência: Diferentes } \\
\text { Olhares }\end{array}$ & $\begin{array}{l}\text { Sordi, A. O. } \\
\text { Manfro, G. G. } \\
\text { Hauck, S. }\end{array}$ & 2011 & $\begin{array}{l}\text { Theoretical Article } \\
\text { (undeclared) }\end{array}$ & $\begin{array}{l}\text { Concept of resilience for the human } \\
\text { sciences, emphasizing the field of } \\
\text { psychiatry. }\end{array}$ \\
\hline $\begin{array}{l}\text { Mother courage: reflections on } \\
\text { maternal resilience }\end{array}$ & $\begin{array}{l}\text { Baraitser, L. } \\
\text { Noack, A. }\end{array}$ & 2007 & Report of Research & $\begin{array}{l}\text { The relation between ambivalence and } \\
\text { resilience. }\end{array}$ \\
\hline Narrative in the study of resilience & $\begin{array}{l}\text { Hauser, S. T. } \\
\text { Golden, E. } \\
\text { Allen, J. }\end{array}$ & 2006 & $\begin{array}{l}\text { Theoretical Article } \\
\text { (undeclared) }\end{array}$ & $\begin{array}{l}\text { It deals with the experience of narrative } \\
\text { and psychotherapy. }\end{array}$ \\
\hline $\begin{array}{l}\text { My life is longing: child abuse and its } \\
\text { adult sequelae }\end{array}$ & $\begin{array}{l}\text { Massie, } \mathrm{H} . \\
\text { Szajnberg, N. }\end{array}$ & 2006 & Report of Research & $\begin{array}{l}\text { It deals with the subject of sexual } \\
\text { abuse, defence mechanism and } \\
\text { personality disorders. }\end{array}$ \\
\hline Narrative in the study of resilience & Harris, A. & 2006 & Theoretical Article & $\begin{array}{l}\text { It explores the psychotherapeutic } \\
\text { process and trauma. }\end{array}$ \\
\hline $\begin{array}{l}\text { Resiliência familiar e conjugal numa } \\
\text { perspectiva psicanalítica dos laços }\end{array}$ & Benghozi, P. & 2005 & Theoretical Article & $\begin{array}{l}\text { It addresses the issue of violence and } \\
\text { trauma through psychoanalytic theory } \\
\text { and in relation to resilience. }\end{array}$ \\
\hline
\end{tabular}

Nota: Tabela desenvolvida pelos autores do presente artigo. Todos os direitos autorais devem estar reservados.

\section{Discussion and Conclusion}

This paper analysed how psychoanalytic scientific productions have treated the concept of resilience in scientific literature. The findings indicate that the concept of resilience in Psychoanalysis tends to be related to other concepts. It indicates an ability that was built fundamentally through relationships: among subjects, between subjects and their environments, and others. Although all studies refute the understanding of anything innate, Benghozi (2005) points out that the idea of transgenerational transmission that may take place in the processes of filiation and affiliation, which is possibly an interesting path for future research given the frequent combination between resilience and intrafamily violence. However, a number of other related questions emerged: How resilience is understood in the field of psychoanalysis? What is resilience as a concept and how technically useful is it? From a psychoanalytic perspective, are there any other concepts that resilience might be associated with, or even mistaken for?

It is remarkable that the majority of the articles (8, see Table 1) are Theoretical Reviews. This information may indicate that the researchers, in fact, aim to theoretically understand how resilience is understood and related to other concepts, as it was possible to verify. However, it has become equally evident that empirical studies are still insufficient and therefore, a question is raised: why are empirical researches less numerous in the psychoanalytic field when one considers the phenomenon of resilience? Is it a limitation in the studies? These are questions that are currently being raised as suggestions for future and continuous research. 
The analysis of articles in this review showed that all studies agree on the notion of resilience as a process that goes beyond simple adaptation. It is in fact an ability to survive (Hauser, 2011), related to intrapsychic capabilities and early emotional experiences (Cabral \& Levandowkski, 2013; LaMothe, 2012; Baraitser \& Noack, 2007). In this respect, resilience emerges as a characteristic that is closely related to the social context of the subject. In fact, it develops from and within this context (Benghozi, 2005; Baraitser \& Noack, 2007).

The results of the research described in this review show that the concept of resilience still encompasses a number of different questions, issues and diverging concepts, and this fact could hamper its understanding. Its broad conceptual scope could well represent theoretical and practical pitfalls and lead researchers to disconcerting questions, such as, "can resilience really be defined?" "Is it a combination of other wellknown concepts?" As previously mentioned, people in diverse areas of psychoanalysis have studied this matter. When we used the word "resilience" by itself as a descriptor, it generated a list of over 3,000 published items in various fields of study, which may indicate that the word is widely used today.

Although the articles reviewed contain similar views about the definition of resilience, it became clear that papers did not use the same concept. This indicates that resilience still not clearly defined in psychoanalytic production. There seems to be a broad consensus that, given its complexity, resilience is a difficult term to define (Rosa, 2012; Sordi, Manfro, \& Hauk, 2011; Brandão, Mahfoud \& Nascimento, 2011; Benghozi, 2005; Harris, 2006; Junqueira \& Deslandes, 2003). Some of the studied authors state that resilience involves several different abilities and resources, ranging from intra-psychic stability to matters of social context. This is surely not an issue that is likely to produce a simple and unanimous answer, nor does it seem to be answered in the material analysed in this study.

Taking into account the confrontation with and overcoming of difficulties from a psychoanalytic perspective, the topic of resilience arises indirectly and is bound up with other concepts and lines of thought. It is believed that the phenomenon is related to the conditions needed for maintaining the ego intact and to the quality of psychic defences that are activated when conflicts arise, even if not explicitly (Rosa, 2012; Hauser, 2006; Anaut, 2005; Benghozi, 2005).

With respect to design, we found more theoretical than empirical studies. One interpretation of this fact may be that the concept of resilience has not yet been incorporated into the theoretical field, or it may be more closely associated with some more traditional concept and consequently does not appear in the literature under this name.

Limitations of the present study include the fact that it covers a limited temporal and theoretical framework. This reduces the possibility for broad generalisations on the topic of resilience, even though the psychoanalytic method focuses on singularity. Other combinations of descriptors could also have been used, considering that many of the articles assessed were closely related to other topics as well and singular features could be seen in all the articles. Nevertheless, the present study identified interesting data regarding psychoanalytic production and raised additional possibilities for research. Finally, it is important to note that this present article is the only systematic review to date addressed to linking the topics of psychoanalysis and resilience. The study design was carefully complied with and its value can be noted.

In addition, many studies in psychoanalysis do not state what design they are based on. For these reasons, it is urgent that psychoanalysts, as well as individuals involved in other branches of science, using the classical connotation of the concept of science, develop new methodological tools for research. The use of systematic reviews as a type of research can therefore generate important reflections for the psychoanalytical field. In addition to providing important information for mapping issues in the sciences, systematic reviews enable access to publications that give greater consistency to the theoretical and technical reflections developed in psychoanalysis.

Therefore, the lack of studies regarding the psychoanalyst's work is underscored, especially on whether or not the concept of resilience can be used as a tool for listening and understanding. All these questions emerged in this study of psychoanalysis and resilience as intersecting elements, considering both the theoretical and the practical contexts of the field. Further research is needed, of course, to move beyond the theoretical field in attempts to answer some of these questions. 


\section{References}

Anaut, M. (2005). A Resiliência - Ultrapassar os traumatismos. Lisboa: Climepsi Editores.

Baraitser, L. \& Noack, A. (2007). Mother courage: Reflections on maternal resilience. British Journal of Psychotherapy, 23, 171-188. https://doi.org/10.1111/j.1752-0118.2007.00016.x

Benghozi, P. (2005). Resiliência familiar e conjugal numa perspectiva psicanalítica dos laços. Psicologia Clínica, 17, 101-109. https://doi.org/10.1590/S0103-56652005000200008

Brandão, J. M., Mahfoud, M., \& Nascimento, I. F. G. (2011). A construção do conceito de resiliência em psicologia: discutindo as origens. Paidéia, 21, 263-271. https://doi.org/10.1590/S0103-863X2011000200014

Cabral, A. S., \& Levandowkski, D. C. (2013). Resiliência e psicanálise: aspectos teóricos e possibilidades de investigação. Revista Latino Americana de Psicopatologia Fundamental, 16, 42-55. https://doi.org/10.1590/S141547142013000100004

Charles, M. \& O'Loughlin, M. (2012). The complex subject of psychosis. Psychoanalyses, culture \& society, 17, 410-421. https://doi.org/10.1057/pcs.2012.30

Cyrulnik, B. (1999). La résilience: Un espoir inattendu. In Cyrulnik, B. (M.-P. Poilpot, org.). Souffrir et se Construire (pp. 13-24). Ramonville: Editions Érès.

Costa A. B. \& Zoltowski, A. P. C. (2014). Como escrever um artigo de revisão sistemática. In Koller SH, Couto MCPP and Hohendorff JV (eds), Manual da Produção Científica. (pp.55-70). Porto Alegre: Penso.

Cruz, S. H., Zanon, R. B., \& Bosa,C. A. (2015). Relação entre Apego e Obesidade: Revisão Sistemática da Literatura. Psico 46(1), 6-15. doi: https://doi.org/10.15448/1980-8623.2015.1.13227

Galvão, T. F., Pansani, T. S. A., \& Harrad, D. (2015). Principais itens para relatar Revisões sistemáticas e Meta-análises: A recomendação PRISMA. Epidemiologia e Serviços de Saúde, 24 (3), 335-342.

Harris, A. (2006). Narrative in the study of resilience. Psychoanalytic dialogues, 16, 543-51.

Hauser, S. T. \& Golden, J. A. E. (2006). Narrative in the study of resilience. The psychoanalytic study of the child, 61, 205-227. https://doi.org/10.1080/00797308.2006.11800771

Junqueira, M. F. P. S. \& Deslandes, S. F. (2003). Resiliência e maus-tratos à criança. Cadernos de Saúde Pública, 19, 227-235. https://doi.org/10.1590/S0102-311X2003000100025

LaMothe, R. (2012). Potential space: creativity, resistance, and resilience in the face of racism. Psychoanalytic review, 99, 851-876. https://doi.org/10.1521/prev.2012.99.6.851

Massie, H. \& Szajnberg, N. (2006). My life's longing: child abuse and its adult sequelae. International Journal Psychoanalysis, 87, 471-496. https://doi.org/10.1516/2R7R-0P2T-69Q4-BX0P

Moher, D., Liberati, A., Tetzlaff, J., \& Altman, D. G. (2009). Preferred reporting items for systematic reviews and metaanalyses: The PRISMA statement. Research Methods and Reporting, 339, 332-336.

Ostermann, G. (2011). Incesto e Resiliência. Revista Brasileira de Psicoterapia, 13, 169-187.

Rosa, G. A. M. (2012). Un aporte de la resiliencia a la clínica psicoanalítica. Revista Psicologia: teoria e prática, 14 , 168-179.

Rooke, M. I. (2015). Aspectos conceituais e metodológicos da resiliência psicológica: uma análise da produção científica brasileira. Estudos e Pesquisas em Psicologia, 15(2), 671-687. https://doi.org/10.12957/epp.2015.17665

Sampaio, R. F., Mancini, M. C. (2007). Estudos de revisão sistemática: um guia para síntese criteriosa da evidência científica. Revista Brasileira de Fisioterapia, 11, 83-89. https://doi.org/10.1590/S1413-35552007000100013

Sordi, A. O., Manfro, G. G., \& Hauk, S. (2011). O conceito de Resiliência: Diferentes Olhares. Revista Brasileira de Psicoterapia, 13, 115-132.

Ungaretti, M. S. (2013). Revisão literária sobre a relação de resiliência com conceitos psicanalíticos. Diaphora. 13(1), 63-69.

Dados dos autores:

Bibiana Godoi Malgarim - Doutora, Universidade Federal do Rio Grande do Sul.

Márcia Rosane Moreira Santana - Mestre, Universidade Federal do Rio Grande do Sul.

Amanda Pacheco Machado - Mestre, Universidade Federal do Rio Grande do Sul.

Andre Goettems Bastos, Doutor - Pontifícia Universidade Católica do Rio Grande do Sul.

Lúcia Helena Freitas, Doutora - Universidade Federal do Rio Grande do Sul.

Endereço para correspondência:

Bibiana Godoi Malgarim

Av. Padre Cacique, 266 ap. 204

90810-240 - Porto Alegre, RS, Brasil

<bmalgarim@yahoo.com.br>

Recebido em: 07.06.2017

Aceito em: 04.01.2018 